\title{
Armed On-board Protection of Dutch Vessels: Not Allowed Yet But Probably Forthcoming
}

\author{
Paul Mevis \& Sari Eckhardt*
}

\section{Abstract}

This article provides an overview of the developments about the armed on-board protection of Dutch vessels under Dutch law. The Dutch position has changed over the years. In 2011, the starting point was that private security companies (PSCs) are not to be allowed. It was expected that adequate protection of Dutch vessels could be provided by vessel protection detachments (VPDs). Although not considered as an absolute statutory bar, the state monopoly on force was considered the main argument against PSCs. After optimising the use of VPDs and given the development in other countries, the approach changed into a 'VPS, unless ...'-approach. Under the new Protection of Merchant Shipping Act that is expected to come into force in the second half of 2019, PSCs can be employed only if no VPS is available. This article gives an overview of the argumentation in this change of view over the years. It also explores the headlines, criteria and procedures of the new law and some other topics, including the position of the master under the upcoming law. In line with the other country reports, it enables the comparative study in the last article of this special issue.

Keywords: vessel protection, private armed guards, state monopoly on force, masters position, state control

\section{Introduction}

The scope and nature of the threat of piracy to the large fleet of Dutch merchant vessels has been the topic of political debate since 2011 between the Netherlands government and Parliament. ${ }^{1}$ The main question in the discussion was whether to allow armed private security companies (PSCs) on board Dutch merchant vessels, and if yes, under what conditions and restrictions. Deploying armed PSCs on board Dutch sea vessels has

* Paul Mevis is professor of criminal law and criminal procedure at Erasmus University Rotterdam. Sari Eckhardt holds a master's degree in criminal law and has worked as a student assistant at the Rotterdam Erasmus University's Department of Criminal Law and is currently working at De Bont Advocaten.

1. G. Scott-Smith and M. Janssen, 'Holding on to the Monopoly on Violence? The Use of Armed Force, the Dutch Approach to PMSCs, and the Anti-Piracy Case', St. Anthony's International Review, at 54-70 (2014) provide for an overview of discussions up to 2013 always been, and on the date of finalisation of this article in March 2019 it still is, prohibited by law. This is so, despite the threat of piracy in its peak years, 2010 and 2011, and despite the fact that companies around the world provide armed security services for seagoing vessels. Theoretically, an attack against a Dutch vessel, with a lot of media attention, could have affected the discussion, but there has been no such attack. Nevertheless, there has been a constant discussion in the Netherlands about whether PSCs should be permitted. Supported by vessel owners and other organisations, and the argument that the Dutch merchant fleet will become less competitive, the calls for allowing PSCs on board Dutch vessels have become stronger over the years. An important rationale underlying this gradual change of mind is that there is an increasing number of flag states in Europe that by law allow on-board PSCs. In the Netherlands, an amendment of law is required to allow armed PSCs on board Dutch vessels. Such amendment is expected to be enacted in the near future because a bill on this subject has (already) passed the Netherlands Parliament (in March 2019), but the bill has not come into force yet. The strong debate in the two Houses of Parliament ${ }^{2}$ focused on issues of legal substance and validity of the proposed provisions and centred on this question of law: does the bill provide enough and adequate provisions for the Dutch government to allow PSCs? Even when the bill will be enacted as an Act of Parliament, many of its provisions will require further regulation by regulations thereunder ${ }^{3}$ before the first armed PSC will be allowed to board a Dutch vessel. In addition, as long as there is no imminent threat of piracy, there is no need for a rapid enactment. ${ }^{4}$ And even if the amendment enters into force, it will allow deploying PSCs under very strict conditions. Until such time, the

2. The Dutch Parliament, the States-General, is bicameral consisting of the House of Representatives and the Senate. A bill has to pass both chambers. A majority in each of the two chambers may accept a bill. Only the House of Representatives can initiate or amend a bill.

3. The Act of Parliament may provide (and the accepted bill does provide as we will see) that matters be further regulated by Order in Council, which is legislation of a lower order than an Act of Parliament. An Order in Council is issued by Royal Decree. Parliament may require to be informed before the Order is promulgated, as it did for almost all of the Orders prescribed by the legislative proposal.

4. International Chamber of Commerce (ICC) and International Maritime Bureau (IMB), Piracy and Armed Robbery against Ships, Report for the Period 1 January-31 December 2017 (London, 2018), available at: https://www.icc-ccs.org/piracy-reporting-centre/request-piracy-report. 
Netherlands will continue to rely exclusively on its armed forces to protect ocean-going vessels - vessel protection detachments (VPDs). The amendment will change the exclusive nature of VPD protection, but its approach will remain 'VPD, unless ...'

This article will discuss the arguments raised in the political debate in the Netherlands on deploying PSCs on board Dutch vessels. Given the absence of practical experience with PSCs on board of Dutch vessels, we will describe the contents of the legislative proposal in the bill as accepted by Parliament. This article will then highlight the rationales underlying the 'VPD, unless ...' approach. We will also discuss how the legislator plans for the system to work when PSCs take firearms on board and, in the worst case, are required to shoot hijackers of their vessels.

\section{Statutory Background - An Overview of Arguments}

\subsection{For the Time Being Current Situation}

The traditional and for the time being current regulatory framework in the Netherlands has three particular features. First, current law does allow for the master of a vessel to have two handguns on board but prohibits possession of more or heavier firearms. This option obviously falls short to meet the threat of modern piracy. Second, the possession or use of these weapons on board may constitute a criminal offense, such as a violation of the gun control laws (possession of guns on board) or, if firearms are used, (attempted) murder or aggravated assault under the Dutch Criminal Code. The government has stated that masters and vessel owners will be prosecuted if they violate these laws. There has not yet been any criminal prosecution, although there have been rumours that some Dutch vessels in fact have private security guards on board. In extreme cases, such violations of Dutch criminal law may cause the government to deregister the Dutch vessel involved. Third, if the master and crew, however, use force against pirates attacking their vessel, they may argue self-defence or necessity when prosecuted. In its judgment of 23 October 1984 the Supreme Court held that the mere fact that prohibited weapons were used in self-defence does not in itself imply that the defendant is barred from arguing self-defence. The mere fact that a master chooses to navigate a piracy-prone area is arguably not enough to deny him the defence of self-defence or necessity for being at fault. On the other hand, as long as there is no imminent threat or attack, there is no need for selfdefence. Therefore, self-defence cannot serve as a justification for possessing firearms on board Dutch vessels because of fear or the possibility of a pirate attack, where such possession is a violation of gun control laws. In addition, as we will see in the following, this justification is not used in the upcoming legislation.

\subsection{The 2011 Advisory Committee on Armed Private Security against Piracy and the Government's Response: 'VPDs Only (for Now)'}

Against the backdrop of the piracy threat, the Dutch government was forced to take a stand in 2011 as to whether it would allow armed private security guards on board Dutch vessels. The government decided to submit the question to the Advisory Committee on Armed Private Security against Piracy ('Advisory Committee'). ${ }^{5}$ The Advisory Committee issued its recommendations in August 2011.6 Although it didn't expressly rule out any possibility of deploying armed private security on board Dutch vessels, it did so preliminarily, thus leaving room for future developments. The government subsequently endorsed this position and so did a majority of Parliament. The Advisory Committee and the government based their assessment on the following arguments.

\subsubsection{State Monopoly on Force}

First, both the Advisory Committee and the government gave much importance to the principle of the state's monopoly on violence, which is a fundamental principle under Dutch public and private law holding that the legitimate use of force by the state cannot be exercised by private entities. There are several reasons for their emphasis on this principle, which echoes deep religious beliefs and philosophies of Dutch politics and society. However, the government's 2011 decision to hold off PSCs also implies - consistent with the Advisory Committee's reasoning - that the government believes the state monopoly on force is not an absolute statutory bar to accepting the use of armed private security on board Dutch vessels. It is not a bar in other countries either.

\subsubsection{Importance of Criminal Prosecution of Pirates}

Second, in its decision to hold off the Dutch government also analysed the rest of its efforts to combating piracy. State action by Dutch armed forces on board Dutch merchant vessels could also promote the international rule of law. The Dutch Constitution requires the government to do so. ${ }^{7}$ For that reason, it is important to seek criminal prosecution of piracy as the crime of hijacking individual vessels ${ }^{8}$ as well as a form of international organised crime. Serious efforts need to be made to locate and prosecute the upper echelons of pirate groups as criminal organisations: the clients, financiers and intermediaries. Criminal prosecution means arrest-

6. The Dutch report contains a summary in English, available at: https:// www.rijksoverheid.nl/documenten/rapporten/2011/09/01/rapportcommissie-de-wijkerslooth-geweldsmonopolie-en-piraterij. There was an earlier advice of the Advisory Council on International Affairs to allow PSCs: https://aiv-advies.nl/download/045f9ea5-c9f0-4bb6-a3c0bc190e56dbaa.pdf.

7. Section 90 of the Dutch Constitution provides: 'The Government shall promote the development of the international legal order.'

8. Punishable under Section 381 of the Dutch Criminal Code and applicable on the basis of universal jurisdiction (Section 4 of the Dutch Criminal Code). 
ing and bringing charges against hijackers, preferably in the region but, if necessary, also in the Netherlands. This is an important (international) obligation which VPDs deployed on board Dutch vessels are better able to organise than PSCs who merely want to save the vessel. Courts in the Netherlands and elsewhere in Europe have gained some experience with this type of prosecution. ${ }^{9}$ The more the Netherlands, together with other countries, can and actually does contribute to combating piracy under international criminal law, the more reason it has to not deploy PSCs as an immediate and unavoidable necessity due to the situation on certain navigation routes. State action against pirates in general is important in this discussion. In this regard, the Netherlands appears to do or wants to do more than many other countries.

\subsubsection{Importance of Other Means of Protection}

Third, in 2011, the government relied on methods other than PSCs to protect Dutch vessels, one particular method being the consistent and proper implementation of Best Management Practices. These include safety measures on board, convoy shipping and joining group transits through the International Recommended Transit Corridor, as well as shipping under the protection of patrolling navy vessels in dangerous seas within the framework of the EU Atlanta mission and the NATO Ocean Shield mission. This argument is supported by the view that the Dutch state is not required to guarantee protection for every risk that every Dutch vessel may encounter on routes anywhere in the world. There is no duty to permit a PSC for each journey with a possible risk for a piracy attack.

\subsubsection{Navy Deployment to Be Optimised First}

The last argument of the Advisory Committee and the Dutch government's decision not to allow armed private security guards on board Dutch vessels in 2011 was that the use of armed private security guards was not necessary. They argued that military VPDs by the Royal Netherlands Navy could provide sufficient and adequate security for individual vessels. One specific rationale was the lack of practical experience in 2011 with deploying VPD for security purposes. At that time, there still was no clarity as to the scope of protection and the number of military VPDs. Before the decision to allow PSCs could be made, VPD deployment had to be optimised first. Since 2011, VPD protection has been optimised and made more flexible and less expensive over the years. As we will see, the answer to the question whether peak flexibility has been reached in 2018 has in recent years been an important factor in the changing approach towards PSCs.

\subsection{The 2017 Bill for the Protection of Merchant} Shipping Act

The government and Parliament initially argued that the use of PSC could not be ruled out but could only be considered when 'an adequate level of protection cannot be offered and the international position of the Netherlands is negatively affected'. This allowed them to reconsider some matters while allowing PSCs on board Dutch vessels. On 26 April 2013, the government ${ }^{10}$ issued a new statement to Parliament about deploying VPDs. ${ }^{11}$ The government expressed its intention to draft legislation allowing the use of PSCs. The government had a variety of reasons for its new position.

The government continued to emphasise adequate protection of the merchant fleet by deploying VPDs. However, one of the most important arguments to allow PSCs was that, in spite of the downward trend in deployment of VPDs, the state cannot always meet the vessel owners' requirements. The government's letter stated that VPDs cannot meet the requirements of the vessel owners in all cases in terms of flexibility in application periods, scope, relative costs or geographical range. Problems arise particularly in transports that are part of the spot market. These are transports for which the destination port only becomes known at a later stage. Furthermore, the Ministry of Defense was not prepared to deviate from the minimum standard size of a VPD of eleven people. Deviation was possible but required a drastic (more expensive) change of the deployment concept. As such, the Ministry of Defense could not transport a VPD if the vessel was not suitable to take on a team of eleven people. Thus, the government's opinion in 2013 was that although VPD deployment had been optimised, their deployment still could not provide security in all cases. The use of VPDs had therefore reached its limit, not because of a lack of defence personnel but because of the size of VPDs, because the time required to organise VPDs differed and was at times very short, and because of pricing (the vessel owner's private contribution could not be reduced further).

There is yet another argument, however. As the government rightly reported in their letter to Parliament, especially in the years after 2011, many countries, including many European countries, have passed legislation to permit the use of PSCs. This fact has contributed to the shift in political opinion. This change is based on the fear that the exceptional prohibition of the Netherlands will affect its merchant fleet's competitive position. Such potential negative effect on the competitiveness of the merchant fleet is a sensitive matter for those Dutch politicians and members of society who consider the country's military and trade history to be heroic. There was a fear that Dutch ship owners would reflag to a country that allows PSCs or that makes enough VPDs

10. On 5 December 2012, the government was comprised of liberals and socialists. The previous government was made up of liberals and Christian democrats. The Minister of Defense was a Christian democrat. Traditionally, Christian democrats are fierce proponents of the state monopoly on force.

11. Parliamentary Papers II, 2012/13, 32 706, 44. 
available. From a legal point of view, it is clear from developments in some other countries that these countries considered that there is a legal basis to allow PSCs. Yet they also considered that it is possible on a PSC certification framework to provide for proper and effective rules to control the use of force by PSCs on board. On these arguments the original, strong argument of the state's monopoly of force started to be less articulated in favour of a more economic approach. It is important to note, however, that the other countries' decision to allow PSCs is based on reasons considered less important in the Netherlands. For instance, in some countries (e.g. Norway, Denmark) there is a major difference between the size of the merchant fleet and the size of their navy. In addition, countries have vastly different legal and cultural opinions about the state's sole right to use force (as seems to be the case in the Anglo-Saxon legal culture). In Germany's case, the limited deployment of its navy is based on its history.

All these arguments taken together led the government to conclude in 2013 that PSCs should be allowed in addition to VPDs and that legislation had to be passed to make this possible. However, it is relevant to note that the government's change of position is not - as the Ministers want to make it appear in their above-mentioned letter of 26 April 2013 - fully consistent with the reasoning and conclusions of the 2011 Advisory Committee's report or the previous government's original position which was based on that report. The government made a new and different political decision. This decision was more than ever before based on the need to facilitate shipping and the belief that the state has a duty of care to protect the economic interests of the industry and the safety of people sailing on Dutch vessels. This indicates the new - politically different - government had less reservations about abandoning the state monopoly on violence to allow vessel owners to use PSCs. This belief was a new element in the debate and was based on notions of international (labour) law, such as Article 94 of the UNCLOS, Article V of the Maritime Labour Convention and Article 2 of the European Convention on Human Rights (ECHR; right to life), in combination with the doctrine of 'positive treaty obligations'. Because the optimised deployment of VPDs and measures by the vessel owners themselves could no longer provide adequate security in all categories of transport, the government considered it necessary to fulfil its duty of care by creating the appropriate conditions for the use of PSCs. Note that international law does not strictly require the state to allow PSCs. The previous government also considered the possibility of not sailing at all, or only at the vessel owner's risk, instead of allowing the use of a PSC on board. The state's duty of care was in that approach not absolute. In addition, the new government became more concerned about economic ramifications if the Netherlands were to prohibit PCSs while other countries did not.

Although there is little to be said against the new political position, the underlying arguments are not very convincing as compared to those raised in the past. In addi- tion, it is based on the mere expectation of adequate legislation and implementation practices to facilitate the use of PSCs. The fact that the government's arguments are not convincing is also apparent from Parliament's reaction to the government's new position. In 2013, a majority in the House of Representatives disagreed it was necessary to allow PSCs on board Dutch vessels in addition to VPDs and to pass legislation to do so. Parliament's position was based on the same questions that were raised in the government's debate: is the use of PSCs on vessels necessary, given all the other options for protection? Can the use of VPDs still be further expanded, for example, by stationing marine forces in the Gulf of Aden or by cooperating with other EU countries? Can the size of a VPD be reduced to less than eleven people, given the fact PSCs as well as other countries' military VPDs work with teams of four to six people? And what are the consequences of differences in size? Is piracy moving from the East Coast of Africa to the West Coast where states do not permit PSCs (and perhaps not even VPDs) on board vessels in their territorial waters? This question was particularly important: can legislation be passed which adequately regulates and provides safeguards for the use of weapons by PSCs on board? Can the master's duties in this regard be adequately regulated? Parliament's response was not entirely negative. However, the questions raised did not convince the majority there was a need to legalise the use of PSCs, even if only complementary to VPD protection. Parliament insisted on further investigation while calling for restraint before making irreversible decisions to allow PSCs on board Dutch vessels.

In December 2015, the Dutch government published another statement to Parliament. The government argued that it continued to prefer public security guards but did not entirely rule out private security guards. ${ }^{12} \mathrm{It}$ continued to adhere to the principle that VPDs could be deployed; however, it specifically addressed two exceptions. The first exception is the situation that there is simply no VPD available. Four other exceptions were described in the government's opinion as follows:

1. Transportation requiring to navigate $100 \mathrm{NM}$ or more to reach the entry and exit point of a VPD in comparison to an entry and exit point of a team of private security guards.

2. Transportation accompanied by VPDs costs the vessel owner 20 per cent or more than deploying private security guards.

3. Transportation by a vessel that cannot accommodate an additional VPD during the period the VPD is on board.

4. Transportation for use in the spot market where the planned route and potential detours render VPD deployment too complicated or impossible.

In these cases, the government's new approach was that private security services holding a Netherlands maritime security license should be allowed on board merchant

12. Ibid., 74 
vessels, subject to strict conditions. It is clearly a 'VPD, unless ...' opinion.

Along this line, two members of the House of Representatives submitted a bill for the Dutch ${ }^{13}$ Protection of Merchant Shipping Act. Their final draft was published in February 2017. ${ }^{14}$ It is this bill that, finally, is accepted by Parliament in March 2019. The bill seeks to elaborate on the above-mentioned 'not for now' PSC approach of the 2011 Advisory Committee, given that experience since 2011 has shown the limits of depending solely on VPDs to protect Dutch vessels in situations that call for protection. And given the development that more and more countries have accepted PSCs. The bill aims to provide adequate security for transports which cannot be secured by VPD (for lack of space, time or costs) and to protect the Dutch merchant fleet's commercial interests. The bill does so by ensuring that transport prices match the prices foreign vessel owners pay to protect their transports. Under this bill, Dutch law will in the near future permit on-board possession and, if necessary, use of weapons. The bill sets forth the legal safeguards deemed necessary for such deployment. The bill's contents and key considerations and issues merit discussion because it is an indication of the contours of future law on PSCs in the Netherlands. This will allow us to judge whether it has the requisite fundamental features. Let us therefore turn to the bill in more detail.

\section{Key Aspects of the Law}

\subsection{Background}

The bill's drafters mainly follow the government's opinion that there are, or better, have become sufficient arguments in favour of allowing PSCs. ${ }^{15}$ Their reason for drafting the bill is the rising number of piracy attacks and their significant impact on the economy. The maritime industry plays an important role in the economy and employment of the Netherlands. Again, much weight is given to the fact that all European countries with a strong maritime presence have promulgated legislation for deploying private maritime security on board merchant vessels. This affects the competitiveness of the Netherlands merchant shipping industry because Dutch vessel owners pay more than foreign vessel owners to protect their vessels. As a result, they miss out on business opportunities, because they cannot meet

13. To expedite the process, the bill only relates to the European part of the Kingdom of the Netherlands. One complication is that ships within the whole Kingdom of the Netherlands fly the Dutch flag, but the Netherlands and Curacao use different ship registers. Applying Dutch legislation to Curacao would require a legislative proposal to go through different legislative processes and to be passed by separate parliaments within the Kingdom of the Netherlands. The idea is that Curacao will make separate but substantially the same provisions as the Dutch law. By a special provision, the upcoming Dutch bill can eventually be replaced by a law, applicable to the Kingdom of the Netherlands as a whole (Rijkswet), but that is not a target as such (Parliamentary Papers I, 2018/19, D, 6)

14. Parliamentary Papers // 2016/17, 34 558, 5.

15. Ibid., 6. the security requirements. The drafters argue this encourages vessels to deregister from Dutch registers and to fly a different flag. This causes the merchant shipping industry and related services (e.g. financing, accounting, repair and maintenance companies, and maritime lawyers) to leave the Netherlands' jurisdiction, making it less attractive to register a vessel under Netherlands law. The drafters argue the playing field could be levelled again by allowing private security services on board Dutch merchant vessels, subject to conditions. This economic argument seems to reflect the shift in the political opinion from embracing the public law concept of state monopoly on violence to advocating the necessity to protect vital economic interests. The approach, consistent with the government's position, is that PSCs should only be allowed if the government cannot provide VPD protection. PSC protection is only allowed where it has been previously decided that VPD protection is not available; PSC protection is only permitted as a substitute to VPD protection. So: 'VPD, unless ...'

\section{2 'VPD, Unless ...'}

It is generally accepted that vessel owners travelling through high-risk areas are expected to use Best Management Practices (BMPs) consisting of procedures with several levels of measurements to prevent pirates from attacking vessels and boarding the vessel. The use of all possible BMPs is seen as condition sine qua non for further protection by VPD or PSC, as the case may be. In the 'VPD, unless ...' approach, the use of PSCs is given a subordinate role. Under the bill, this means that when a VPD or another form of government protection is available, the vessel owner must accept that form. The vessel owner will be eligible to receive private security services, only if the transport meets the protection criteria and no VPDs are available. The bill's explanatory memorandum distinguishes four specific situations that we already mentioned earlier.

1. Even though VPDs are deployed in more cases, they cannot always be deployed, especially on the spot market as we saw earlier. The main impediment is the difficulty of organising VPD protection on short notice.

2. The vessel in question has no adequate facilities to host a VPD of eleven persons.

3. Economic factors of VPD protection would cause unwarranted changes in the planned navigation route by 'more sea miles than a certain amount to be further stipulated by the Ministry'. ${ }^{16}$

4. The costs of engaging VPD protection are disproportionately higher than PSC protection; the percentage to be stipulated by the Ministry. ${ }^{17}$

In these situations, the drafters saw a discrepancy between the government's duty to organise protection (duty of care) and the impossibility of organising such

16. The distance of 100 NM mentioned above in the government's 2013 memorandum serves as an indication.

17. The 20 per cent figure mentioned above in the government's 2013 memorandum serves as an indication. 
protection through VPDs. In order to correct the discrepancy, the drafters proposed to allow deploying armed private security guards only in these situations. Under this principle of 'VPD, unless ...', it first has to be determined whether VPD protection is at all feasible. The vessel owner must obtain specific permission for each transport to deploy private security guards. The vessel owner has no discretion in choosing between VPD or PSC or in deciding whether based on the above criteria his situation allows him to do without a VPD. Under the bill, this judgment is reserved to the Dutch Coast Guard acting on behalf of the Minister of Justice and Security. Using a PSC without this previous permission is, as we will see in the following, a separate criminal act.

Furthermore, the use of PSCs will only be allowed in dangerous areas. The Ministry will designate these areas based on the high-risk areas set forth in the ILO's BMP document. It also designates so-called Voluntary Reporting Areas (VRAs).

The deployment of private securers is only allowed by private services holding a license issued by the Minister of Justice and Security (issued by the Environmental and Transportation Inspection). Only ISO 28007-1:2015-certified organisations are eligible for licenses. (Licenses of other EU countries will be accepted as well as those from other countries that meet certain criteria.) The license may contain further regulations, such as the requirement of video surveillance and recording of all activities of the PSC through body cameras or the requirement that the PSC be sufficiently insured. A license can be suspended or withdrawn by the Minister.

\section{The Use of Force and the Relation between the Master and the Guards/Team Leader}

The upcoming bill for the Protection of Merchant Shipping Act addresses the use of force because this is a matter of domestic law (including criminal law).

\subsection{General Legal Background}

Despite the political shift from favouring the protection of vital interests of Dutch economy over the state monopoly on the use of force, the bill shows Dutch politics is still reluctant towards armed PSCs. That is the bill's legal background. For a proper understanding, we highlight two important aspects.

The first aspect is that even if the state of the Netherlands were to accept PSCs, the state will remain responsible for any use of force on Dutch vessels, based on for example, the ECHR. Indeed, anyone on board a vessel sailing under Dutch flag and everything that happens on board fall under the Netherlands' jurisdiction, to use the term of Article 1 of the ECHR. When it comes to using violence against pirates on board, the Netherlands - as an ECHR member state - will be responsible for proper treatment of those pirates harmed by its use of force or arrested as perpetrators. As such, these people have a right to adequate medical care, to have any potential human rights violations investigated and compensated, especially their right to protection of their life under Article 2 of the ECHR. They also have due process rights as suspects, including the right to be promptly taken before a court or other authority, even if they are arrested on the high seas, as required under Article 5(3) of the ECHR. It should be noted that the ECHR recognises that it may take some time to take an arrestee from the high seas to court. It is settled case law in the Netherlands that all these duties are best discharged by maintaining the monopoly on force and only allowing the state's armed forces (VPDs) on board Dutch vessels. This will ensure the use of force and its ex post justifications are clearly and adequately regulated and properly governed by the rule of law. This was and still is a strong argument in Dutch politics against the use of PSCs.

The second aspect concerns the right to self-defence as a legal defence and is in some way related to the first. Although the bill for the Protection of Merchant Shipping Act clearly seeks to allow Dutch vessels to protect themselves against piracy, self-defence is not the underlying normative principle of the bill. First of all, as stated earlier, possession of firearms on board Dutch vessels is a per se violation of law as well as the criminal provisions of the gun control laws. Under Dutch criminal law, self-defence is only allowed when there is an imminent attack or threat thereof. The bill regulates onboard possession of firearms (while further regulating proper storage etc.) separately from their eventual use. The bill thus seeks to enhance the vessel owners' protection of their vessels. However, self-defence is not the underlying legal principle on which the bill's legal framework is based. Instead, it is based on the recognition that we need a system to control possession and - if necessary - the use of (fire)arms, given that there is a need for protection in dangerous waters. The bill seeks to regulate possession and use of firearms on board of Dutch vessels within the legal framework. Dutch law recognises self-defence as an exception in very specific situations where an imminent threat makes it impossible to abide by the law.

\subsection{Specific Provisions}

According to the bill, armed private security forces may use force when performing their maritime security services. The bill calls for further, delegated regulation to indicate which weapons and other means of force are allowed and how they have to be stored on board. If there is a threat of piracy, the security forces may carry, set up and threaten with their designated means of defence. If the threat continues and there is no other peaceful way to neutralise the threat, they can use the appropriate level of force as necessary. However, they 
must issue a warning before using force. They may not use force simply to kill, although the provision in question does not prohibit fatal shootings if absolutely necessary. Here again, the justification is that use of force is consistent with this particular statute, not that the PSC acted as required under the specific self-defence provision of the Dutch Criminal Code.

The maritime security guards are allowed but not required to arrest pirates when they observe them committing a crime (according to a general provision in the Dutch Code of Criminal Procedure) and to use handcuffs (according to the bill). Arrestees must be brought before the vessel's master, who now acting as a law enforcement officer, has to proceed as prescribed in the special provisions in the Code of Criminal Procedure applying to the master. This aspect of Section 10 of the bill reflects the Dutch approach following the Advisory Committee's 2011 report not only to prevent piracy but also to arrest and prosecute pirates, if necessary in the Netherlands. It also shows the Netherlands accepts a certain level of responsibility for pirates on board Dutch vessels.

The following provisions are relevant in relation to state oversight and control. Civil servants designated by Ministerial Order must ensure compliance with the Act. The Environmental and Transportation Inspection is charged with overseeing the maritime security companies holding maritime security licenses. It must perform its oversight duty under the auspices of the Minister of Justice and Security. Because the security services will also take place outside the territory of the Netherlands, the oversight duties must be performed on board vessels docked in the harbours of other countries. In case of any irregularity, further investigation may follow and depending on the outcome measures may be taken, such as fines or revocation or suspension of licenses.

The Economic Crimes Act (in Dutch: 'Wet op de economische delicten') will criminalise violations of the prohibition to offer or perform armed maritime security activities without a license granted by the Minister, or to perform, permit or enable armed maritime security activities on board a vessel without the Minister's permission. Dutch criminal law allows for prosecution of legal entities, such as PSC companies. Furthermore, the master's failure to report any use of force and use of handcuffs to the public prosecutor will be criminalised as well. The penalty for violating these rules is imprisonment for six months or a fine of the fourth category (ranging from $€ 8,201$ to $€ 20,500$ ).

Upon completion of each transport accompanied by private maritime security guards, the master and the head of PSC each must draft a separate report in the Dutch or English language as provided in the rules which will be promulgated by further regulation (Order in Council). The reports must state whether and what force or handcuffs were used. Once the threat of piracy subsides, the master must promptly report any use of force and any use of handcuffs by the private maritime security guards to the public prosecutor.
In this respect, the bill has been amended significantly on a certain point by the House of Representatives during the debate in Parliament in an effort to obtain a parliamentary majority in favour of the bill. The relevant part, Section 11 (paras. 1 and 2) of the bill states:

1. In discharging their maritime security tasks private maritime security guards shall use cameras and microphones.

2. Audiovisual recordings must be made from the moment there is a threat of piracy until such time the threat has subsided or is deflected. The recordings will be saved in files. ${ }^{18}$

The team leader has to hand over all video and audio recordings to the master who, in turn, has to transfer them to the public prosecutor as part of his duty to report any threat or use of force or handcuffs. The public prosecutor will then decide whether the use comported with the existing laws, particularly whether there has been any violation of any criminal laws. If he has a reasonable suspicion there has been such violation, he may conduct further criminal investigation or bring criminal charges. Prosecution may result in acquittal if the court finds that the use of force comported with the provisions of the bill. If the court so finds then, again, such acquittal will not depend on the Criminal Code's self-defence provision. However, if the team leader, master or PSC member failed to follow the rules of the bill, they may invoke that provision to raise self-defence as a defence. This is mainly a theoretical position because the law imposes a higher duty of care on the team leader.

To summarise, the use of force is governed by criminal law with its top law enforcement officer - the prosecutor. Once the bill becomes law, time will tell how this system will work in practice. What is clear is that strict regulation of the use of force in the cases where the bill allows for the use of firearms is a reflection of a sensible form of government control. It is an elaboration of the state monopoly on force as well as a key feature of the Dutch approach.

\subsection{Master's Role}

Unsurprisingly, the master's position and responsibilities were a sensitive topic in the discussion which was subject to much debate. In particular, the Dutch organisation of masters was not as keen as vessel owners to accept PSCs on board. On the one hand, the government argued vessel masters could not be held responsible for everything that happens on board if PSCs are engaged. On the other hand, it is clear that under international maritime law the master has a broad level of responsibility. From a Dutch perspective, it is common to vest military team leaders of a VPD with responsibility because they are military commanders under Dutch law. In case of PSCs, there is the risk of 'cowboys at sea' and of a certain legal uncertainty about the master's role. The bill uses a dual approach when it states that 
the maritime security guards are not allowed to use violence until their team leader orders them to do so, unless such orders cannot reasonably be awaited. The team leader may only order use of force after consulting the master who must agree that passive and active antipiracy measures have failed to mitigate the risk of piracy, unless they cannot reasonably engage in such consultation or they cannot reasonably wait for its outcome. Consequently, the bill expects the team leader and the master to confer to a certain degree, but the extent to which they have to confer in the light of the responsibilities at stake is not completely clear. After reading this, one might appreciate that a master will not feel entirely comfortable and clear about his position and responsibilities in this respect. The parliamentary debate provides more insight, stating:

The vessel owner and the master are responsible for complying with the ILO's Best Management Practices ('BMPs'). Whenever a master engages the assistance of armed private security guards, he will be responsible for ensuring both before and during the journey that any such active and passive protection measures as could reasonably be adopted are in fact adopted. These would include changing course, increasing speed, using laser beams, water cannons, barbwire, and so forth. The master is at all times responsible for navigating and operating the vessel. The team leader and the maritime security company will be in charge of using force. The team leader, not the master, will instruct them to do so. ${ }^{19}$

\section{And:}

And lastly, the master's role. The private security guards are personally responsible for their operations. The master is not the one directing the team's operations in threatening situations - that is the duty of the team leader. However, the master will continue to have overriding authority, as set forth in the United Nations Convention on the Law of the Sea. The master may use that authority, for instance, in the exceptional situation where he believes the team is using disproportionate force. ${ }^{20}$

Let us analyse this from the perspective of criminal liability. For instance, if a PSC member shoots a pirate on board a Dutch vessel, then arguably that member will be liable. If he had not yet received any orders to use firearms or any warnings and so on, then it may be safe to conclude that he operated outside the scope of this team's duties. Again, he may raise the defence of selfdefence. Ordinarily, the team leader who ordered the use of force will be the first to be held liable. Under Dutch Criminal Procedure Law, the shooting and killing has to be reported to the prosecutor (accompanied by video and audio footage). As such, the prosecutor has discretion to decide who will be the (prime) target of

19. Parliamentary Reports II, 2017/18, 34 558, 57-32, 16.

20. Ibid., 24 and Parliamentary Reports I, 2018/19, 34 558, C, 3. any criminal investigation or prosecution. The bill seems to make the team leader the main target of the criminal investigation, although it is clear that the master in the end, bears full responsibility, not only under criminal law but under civil law too for that matter. ${ }^{21}$ If the master forbids the team leader to take any action, the latter has to accept this decision of the former. ${ }^{22}$ The master will only be held criminally liable if it is clear that the PSC or its team leader made disproportionate use of firearms and force, such that the master had a duty to intervene with his overriding authority under international maritime law, in the absence of which he will be held liable. ${ }^{23}$ This will only happen under exceptional circumstances and therefore in rare cases only (one must hope). This might be different, though, if the circumstances under which the PSC had to work on board, for which the master is responsible, were generally so bad and poor that they may have contributed to the improper use of force. Poor overall conditions on board the vessel where the PSC is deployed may even reach a level where the vessel owner is so reckless that he might be held criminally liable for the results of the use of force too.

\section{Conclusion}

The bill for the Protection of Merchant Shipping Act has, surprisingly, not that much been discussed by Dutch legal commentators. As far as it is discussed recently, ${ }^{24}$ the approach is accepted, although there is discussion about the state responsibility under international law. ${ }^{25}$ The bill has passed the two Houses of Parliament by March 2019 and is expected to come into force somewhere in the future. In the intense discussion in Parliament the debate centred on three substantive issues.

The first point of debate is the substantive difference between a VPD and a PSC. The Dutch Ministry of Defense argues eleven people should be the minimum number for an effective VPD. The average size of PSCs is four persons. It was tried to explain this significant difference by stating that VPDs have their own basic medical care and operate differently. They operate from several points on the vessel and not, as PSCs, from one central position, which is often the bridge. In addition, VPDs carry out all the security tasks themselves, where-

21. Parliamentary Reports I, 2018/19, 34 558, C, 5

22. Ibid., F, 2.

23. This means that the above quote from the parliamentary debate ('The master may use that authority, for instance, in the exception situation where he believes the team is using disproportionate force') must be read as stating that the master should use his authority under these conditions.

24. C. Ryngaert, De nieuwe wet ter bescherming van koopvaardij, Ars Aequi 2018/787.

25. Ibid., and L. Roorda, C. Ryngaert \& B. Straeten, 'Private beveiliging in strijd tegen de piraterij: een onderzoek naar de aansprakelijkheid van private beveiligers en de Staat', in I. Giesen, J. Emaus \& L. Enneking (eds.), Verantwoordelijkheid, aansprakelijkheid en privatisering van publieke taken (Den Haag, Boom, 2014), 165-188. 
as PSCs also engage the crew to be on the lookout, for example. However, this does not explain the significant difference completely. The question is whether PSCs will exercise enough care and restraint in using proportionate force or avoiding it whenever possible. This is an important argument of the Dutch 'VPD, unless ...' model, an approach that assumes a certain compatibility and equality in the level of protection and guarantees between VPDs and PSCs.

The second point is also connected to this 'VPD, unless ...' approach. One of the main categories in which a PSC might be allowed is - as mentioned earlier - the category of transports connected with the spot market. Here, insufficient flexibility of VPDs is the main reason for engaging PSCs. Against this background, the 'VPD, unless ...' approach seems somewhat ironic because the merchant sector represents seventy-five per cent of the spot market. ${ }^{26}$ In theory, if PSC might be used for all transports in this spot market, PSCs may become the rule rather than the exception.

The third issue is about the master's role and responsibilities. Notwithstanding a certain level of 'understanding' between the master and the team leader on the necessity of the use of force that the bill provides for and the explanation on this point in the parliamentary discussions, as quoted previously, it is still not completely clear who ultimately bears responsibility and what he is responsible for. Under the general approach of maritime law, there can be hardly any discussion about the overall authority and ultimate responsibility of the master. But is he (or should he be) responsible for PSC's use of force against pirates?

If the bill ultimately passes, it will still take some time before the first PSC boards a Dutch vessel. Further regulations have to be made and have to be approved, and several entities have to discharge their duties under the Act. And even then the Netherlands' stance on private armed guards on board Dutch vessels will still be ambivalent. It has emphasised the importance of the state monopoly on force. However, private entities cannot use the legitimate force used by the state. Although this principle is not insurmountable, it calls for restraint. The monopoly on force as a theoretical argument has been supported by the Dutch Royal Marine's practical experience in offering significant on-call assistance to vessel owners to protect their vessels. And although the political stance has changed over the years - giving more weight to protecting vital economic interests - the approach is still a public law-oriented system of strict ex ante and ex post control. Under the 'VPD, unless ...' approach, PSCs are only accepted under a 'condition of subsidiarity', to use EU terminology. It is not for the vessel owner to decide whether he can use a PSC. He needs permission per transport and must accept a VPD, if available. Even when the Netherlands have passed its PSC legislation, its approach will still make its position unique as compared to the legislative frameworks of other countries. Last, from a legal point of view the 'proof of the pudding is in the eating.' Will the Dutch law provide adequate control of the use of private armed guards in general and in each case when force is used, so as to comply with both the fundamental principles of public law of the Netherlands and international law, including human rights? But we may not get to the pudding. Given the diminishing threat of piracy, the debate - and the Act - may wither, 'die in silence'. As a Dutch newspaper stated previously after the bill was accepted in (one of the Houses of) Parliament, 'The anti-piracy law is here but where are the pirates?' 